sciendo Порівняльна професійна педагогіка 9(2)/2019 Comparative Professional Pedagogy 9(2)/2019

DOI: $10.2478 /$ rpp-2019-0014

$\mathrm{PhD}$ in Pedagogy, Associate Professor, OXANA ROGULSKA Khmelnytskyi National University Address: 11 Instytutska St., Khmelnytskyi, 29016, Ukraine E-mail: oxana.rogulska@gmail.com

$\mathrm{PhD}$ in Pedagogy, Associate Professor, OLGA TARASOVA Khmelnytskyi National University Address: 11 Instytutska St., Khmelnytskyi, 29016, Ukraine E-mail: tarasova20olia@gmail.com

\title{
POLISH EXPERIENCE OF FOREIGN LANGUAGE TEACHERS' TRAINING
}

\begin{abstract}
Studying the experience of foreign language teachers' professional training in developed foreign countries opens up new opportunities for improving the system of pedagogical education in conditions of its adaptation to the requirements of the European educational space. Of a significant scientific interest are the progressive achievements of countries that demonstrate a high level of foreign language teachers' professional training in accordance with international standards; have rich historical traditions of education that contributes to their leading role in science and education at the regional and global levels; have gained considerable experience in the field of foreign language teachers' professional training in the new socio-cultural conditions. It is emphasized that the language policy of the European Union demonstrates the crucial importance of language learning in the integration processes. It is also underlined that in modern international documents on the modernization of the foreign language teachers' professional training it is stated that modern educational transformations should facilitate the implementation of a European dimension in the foreign languages teachers' training. The establishment of new values related to the search for a multicultural, multi-ethnic and multi-linguistic Europe depends to a great extent on the ability of the teacher to develop a European consciousness and an individual sense of moral responsibility in a pluralistic society. The paper presents the results of collective scientific research, in particular, the peculiarities of the foreign language teachers' professional training in Poland are presented and the recommendations on the creative use of constructive ideas of the progressive experience in the process of updating the system of pedagogical education are outlined.
\end{abstract}

Keywords: future foreign language teachers' training; institutions of higher education; the European Union; Poland.

\section{АНОТАЦІЯ}

Вивчення досвіду професійної підготовки викладачів іноземних мов у розвинених зарубіжних краӥнах відкриває нові можливості для вдосконалення системи педагогічної освіти в умовах ї̈ адаптаиї̈ до вимог європейського освітнього простору. Значний науковий інтерес викликають прогресивні досягнення крайн, які демонструють високий рівень професійної підготовки вчителів іноземної мови відповідно до міжнародних стандартів; мають багаті історичні традиџї̈ освіти, що сприяє їхній 
sciendo Порівняльна професійна педагогіка 9(2)/2019 Comparative Professional Pedagogy 9(2)/2019

провідній ролі в науці та освіті на регіональному та глобальному рівнях; отримали значний досвід у професійній підготовці вчителів іноземной мови у нових соиіальнокультурних умовах. Підкреслюється, що, відповідно до мовної політики Свропейського Союзу, вивчення іноземної мови займає провідне місче у процесах інтеграції. Також підкреслюється, що в сучасних міжнародних документах щэодо модернізачії професійної підготовки вчителів іноземної мови зазначається, щүо сучасні освітні трансформації повинні сприяти впровадженню європейського виміру в підготовці вчителів іноземних мов. Створення нових цінностей, пов'язаних з пошуком мультикультурної, багатоетнічної та багатомовної Свропи, значною мірою залежить від здатності вчителя розвивати європейську свідомість й індивідуальне відчуття моральної відповідальності в плюралістичному суспільстві. У краӥнах Європейського Союзу підготовка вчителів іноземної мови здійснюється, переважно, закладами вищої освіти, які готують вчителів 30 іноземних мов, хоча цей показник варіюється від краӥни до країни. У статті представлені результати колективних наукових досліджень, зокрема, особливості професійної підготовки вчителів іноземної мови в Польщі та рекомендації щодо творчого використання конструктивних ідей прогресивного досвіду в проиесі оновлення системи педагогічної освіти.

Ключові слова: підготовка майбутніх учителів іноземної мови; заклади вищяої освіти; Свропейський Союз; Польщча.

\section{INTRODUCTION}

One of the initiatives of the Council of Europe and the European Union is the development of new approaches to language teaching and language learning. The European Union in this area follows the idea of multilingualism that is a political slogan and the EU action program. It is declared that the purpose of EU language policy is to preserve the linguistic diversity of the community and provide for its citizens the possibility to master foreign languages. Europe is trying to form an open, multilingual, intercultural society with substantial cultural and linguistic heritage, with all the obvious diversity at the local, regional and national levels. Schools have to play a significant role in the process of teaching and learning modern languages, so the problem of the future foreign language teachers' professional training remains the key one to the Council of Europe and the European Union.

\section{THE AIM OF THE STUDY}

The aim of the article is to present the results of comparative scientificpedagogical research focused on studying the experience of foreign language teachers' professional training in Poland.

\section{THEORETICAL FRAMEWORK AND RESEARCH METHODS}

The problem of the future foreign languages teachers' training was studied by R. Allan (2007), A. Fenner (2007), A. Gallagher-Brett (2018), M. Grenfell (2018), A. Hilmarsson-Dunn (2018), M. Jakowicka (2008), B. Jones (2007), M. Kelly (2018), H. Komorowska (2007), B. Kwiatkowska-Kowal (2015), D. Newby (2007), L. Richard (2018), K. Soghikyan (2007), G. Williams (2012). The following research methods were used: analysis, synthesis, comparison and generalization.

\section{RESULTS}

The language policy of the European Union demonstrates the crucial importance of language learning in integration processes. An increase in the importance of language policy has also affected the structure of the European Commission. On January 1, 2007 a separate position of the EU commissioner on issues of multilingvism was created. It is 
sciendo Порівняльна професійна педагогіка 9(2)/2019 Comparative Professional Pedagogy 9(2)/2019

currently headed by Leonar Orban from Romania. He is the head of the general directorate of the European Commission for translation services, the general directorate of interpreting and the Official Publications Office of the European Communities.

In modern international documents on the modernization of the foreign language teachers' professional training, such as 'Professional Teacher Training and its Development' (2008), the report of the Council of Europe 'Results of Strategic European Cooperation in Education and Training' (2009), it is indicated that modern educational transformations should facilitate the implementation of a European dimension in the foreign language teachers' training process. The Council of Europe has also highlighted its initiative in the following publications: ERLE 'European Recommendations on Language Education: Learning, Teaching, Evaluation' (2001) and ELP 'European Language Portfolio', which are presented as a tool for solving the problem of mastering a foreign language. The new tool for unifying the requirements for the professional competence of language teachers is the so-called European Portfolio for the Teachers of Languages (EPOTL), developed during 2004-2007 by an international group of experts commissioned by the European Center for Modern Languages at the Council of Europe. This is a document created with the support of teachers and lecturers of pedagogical institutions of higher education from the 33 member countries of the European Center for Modern Languages, which summarizes the knowledge and skills necessary for language teaching and learning and helps future foreign language teachers to self-assess the acquired didactic competencies and monitor their own progress in the process of professional competence mastering (Newby et al, 2007).

The mentioned documents state that the implementation of changes is possible only with the development of cooperation and convergence in the sphere of foreign language teachers' training, especially English as a modern international language of the media age. The foreign language teachers must meet the requirements that are put forward to them in the context of modern European linguistic policy. The implementation of ideas of the Bologna Process and the recommendations of the Council of Europe in the foreign language teachers' training requires preparation of professionals of a new generation who are completely ready to professional activity, effective performance of their professional duties, mastering of at least two foreign languages (Common European Framework of Reference for Languages: Learning, teaching, assessment, 2001).

The study of pedagogical sources shows that in the countries of the European Union, the foreign language teachers' training is mainly carried out by institutions of higher education, which prepare teachers of 30 foreign languages, although this indicator varies from country to country (Williams, 2012). Almost all European countries provide training for teachers of English, French, and German. Italian, Spanish and Russian language teacher training programs are also common. The largest selection of foreign languages for studying is offered in Austria, Bulgaria, the Czech Republic, Finland and France. In addition, students are encouraged to study at least one 'uncommon' European language. This provides the realization of one of the key tasks of the European community, i.e. the provision of linguistic diversity (The Training of Teachers of a Foreign Language: Developments in Europe, 2012).

Organizationally, each country has its own teacher training system, reflecting national needs, history and traditions. At the same time, considering the tendency of integration in higher education, the gradual introduction of common models and the adaptation of existing systems to the requirements of the present are observed in teacher training. The report of the European Commission Directorate in the field of education and 
culture (The Training of Teachers of a Foreign Language: Developments in Europe, 2012) presents the results of the state of foreign languages teachers' professional training in European countries. The investigation was conducted on the basis of the English University of Southampton in 2012. The following aspects of the problem were analyzed: the peculiarities of the foreign language teachers' training process for students of a certain age group (for elementary school, secondary school, higher education and adult education); the use of autonomous or distance learning in teacher training; involvement of mentors in the organization of pedagogical practice; Europeanisation of teacher training programs (for example, the use of transnational programs, establishing professional contacts with colleagues in other countries); increasing the level of practical mastering of foreign languages; training of methodologists in the field of teaching foreign languages.

Poland, as a country with a decentralized education system, is actively implementing reforms in pedagogical education, developing modern standards for highquality teacher training in higher education institutions. Scientific interest in the experience of this country arose due to the fact that Poland and Ukraine have much in common in the cultural and socio-historical development. The future foreign language teachers' training in Poland is provided by: 78 pedagogical colleges of foreign languages ( 45 colleges provide English language training); 37 higher vocational schools (including institutes); 19 universities; 7 academies and 1 polytechnic (total - 109).

As a result of the analysis, we can state that in Poland the guiding normative document is the Standard of a foreign language teacher professional training. The Polish Standard of a foreign language teacher professional training defines: general requirements to the foreign language teacher professional training; characteristics of the graduate; basic skills (foreign languages teachers' training should ensure the acquisition of competences in professional areas of knowledge); contents of educational disciplines; goals and requirements for the implementation of psychological and pedagogical practice at school (Reporting stanie edukacji, 2015).

The standard a foreign language teacher professional training coordinates and organizes the training process, providing the basis for the content of foreign languages teachers' training. This allows the preservation of a single educational space in a multinational society and stimulates the differentiation of education. Standardized requirements for teacher qualification are presented in the form of professional competencies. It is imperative that teachers' training programs should be based on their professional competences and reflect their content.

According to the state standard, a foreign language teacher in Poland must be aware of the following spheres of pedagogical activity: 1) the chosen major, in order to competently transfer the acquired knowledge, to deepen and update them on their own, and be able to integrate into other areas of knowledge; 2) psychology and pedagogy, in order to perform educational and mentoring function, to support the comprehensive development of students, to individualize the learning process, to meet the special educational needs of students, to organize the educational process in class, school and local environment, and to cooperate with other teachers, parents, carry out extra-curricular work; 3) educational subjects, in order to effectively conduct training sessions, to support students' intellectual development through the ability to choose the right active methods and technical means of teaching, adequately assess the achievements of students; 4) the use of information technologies during the lessons; 5) mastering another foreign language at level B2 in accordance with the 
sciendo Порівняльна професійна педагогіка 9(2)/2019 Comparative Professional Pedagogy 9(2)/2019

European Recommendations on Language Education (Rozporządzenie ministra edukacji narodowej z dnia 18 lipca 2006 r., No. 128, poz. 897, 2006).

Professional training of a foreign language teacher encompasses studies at the first degree with the title of licensee (corresponding to the educational qualification level, 'Bachelor'). Training lasts 6 semesters. The number of studying hours should be at least 2000 , and the number of ECTS credits is not less than 180. As for the qualification requirements, the foreign language teacher must have basic knowledge of language, literature and culture in the field of the chosen foreign language, as well as the ability to use knowledge in professional activities. The future foreign language teacher should learn a foreign language as a mother tongue, at level B2 in accordance with the European Recommendations on Language Education of the Council of Europe, and must be able to use a foreign language in educational work.

The contents of the basic curriculum for the training of foreign language teachers are divided into three groups. The first group is the subjects of the philological cycle of training, which include (Kwiatkowska-Kowal, 2015): training in the field of practical English language (acquisition of language skills in writing, reading, listening, speaking; integrated competence; practical grammar; practical phonetics; theory and practice of translation; perfect knowledge of a foreign language and ability to use it efficiently in communication and writing); preparation in the field of practical course of the second foreign language; preparation in the field of knowledge of language and communication (introduction to linguistics, language history, descriptive grammar of a foreign language, the theory of the use of contrastive research, the theory of formal grammar with the use of language programming); training in the field of literature and culture (the history of writing or oral traditions of the language studied, taking into account literary genres - poetry, drama, prose, problems of periodization of the history of literature, introduction to literature studies); training in the field of the methodology of a foreign language teaching (problems of foreign language studying and theory of linguistic communication; psycholinguistic foundations of language).

The second group of disciplines includes the subjects of a pedagogical cycle: psychology, pedagogy, didactics, pronunciation, educational law (the organization and functioning of the educational system and the regulation of the activity of educational institutions), ethics, language culture, the history and culture of the native land. The third group of disciplines combines the subjects of general training (information technology and physical education) and pedagogical practice. A student of a pedagogical college of foreign languages must be prepared to use information technologies that play an important facilitating role in conducting lessons. The IT training program is at least 30 hours. Training programs also include studying classical languages (Latin, Old Slavic or Sanskrit) for at least 30 hours.

After the analysis of the cycles of professional of a foreign language teacher the place of theoretical and practical disciplines in the student's training was determined. Thus, the largest number of hours for practical classes is provided by the Pedagogical Collegium of Foreign Languages in Bydgoszcz (89 \%), and the smallest number of hours is Bialystok University and PWS in Krosno (77 \%, $78 \%$ ), respectively, these two educational institutions implement the largest number of hours for theoretical subjects ( $22 \%, 23 \%)$.

The implementation of practices at Polish higher education institutions is presented in two forms: assistant practice and subject-methodical practice. Among the reviewed educational programs of Polish educational institutions, 5-7 \% of the total amount of training is related 
to practice at school. Students have obligatory school practice (180 hours: 150 hours of basic specialization and 30 hours of additional specialization). Polish scholars have suggested improving the content of pedagogical education by introducing content modules from various academic disciplines (in the basic part of the training). Consequently, the emphasis is placed on the priority of the student-teacher cooperation at an institution of higher education and at a school (or other educational institution).

As a rule, at the 3-year educational qualification level, 'license' (pol. licencjat) includes two student practice sessions. The first, so-called general pedagogical practice is expected after the second semester and lasts for three weeks (in general up to 60 hours). Its purpose is the practical verification of studying and the acquisition of competences, including: educational reality and the daily work of teachers; the formation of new skills (cognitive, conceptual, psychological, social (in the context of educational, behavioral and mentor work), the initiation of the process of identification with the profession and the creation of the individual concept of educational work, strengthening the motivation for further academic and practical training. The next, so-called 'specialized' practice is expected after the IV semester, its term is extended to six weeks (by 3 weeks in kindergarten and primary schools). It usually takes up to 120 hours. The purpose of this practice is to verify and apply the knowledge and skills accumulated during the training, as well as in practical training for the performance of professional duties, and the tasks include not only observation, but also active participation of students-practitioners in organizing and conducting various forms of activities under the guidance of a teacher-curator, as well as mandatory summer practice (after IV semester).

During the 2-year master studies 150 hours are usually devoted to practice, in particular, in the second semester 90 hours (3 weeks) and in the third semester 60 hours ( 2 weeks). This practice is aimed at: familiarizing with the organization of the functioning of various types of educational institutions, especially those where graduates can be employed; receiving skills in planning, conducting and documenting classes, as well as analyzing the work of teachers and students, their own work and its results (Regulamin organizacji i realizacji praktyk pedagogicznych realizowanych w ramach projektu "Nowa jakość praktyk pedagogicznych", 2016).

Thus, the Standard of a foreign language teacher professional training ensures high quality of education in the national context of Poland and a prerequisite for effective teacher training for the teaching of a foreign language in various educational institutions. This document contains general requirements for teacher training, a description of the future teacher of a foreign language, his/her professional competencies, groups of subjects and their contents. And, of course, all pedagogical educational institutions use standard requirements as a model for developing their own curricula, depending on the level of knowledge and needs of students. As a result of the analysis of programs, it can be stated that in the future foreign language teacher training in Poland an integrated approach is used. It enables students to synthesize theoretical knowledge with practical skills for skillful work at school.

\section{CONCLUSIONS}

Analysis of national systems of professional training of foreign language teachers in foreign countries made it possible to formulate the following conclusions. The establishment of new values related to the search for a multicultural, multi-ethnic and multi-linguistic Europe depends to a great extent on the ability of the teacher to develop a European consciousness and an individual sense of moral responsibility in a pluralistic society. The key features of the professional training of foreign language teachers in Poland are: 
sciendo Порівняльна професійна педагогіка 9(2)/2019 Comparative Professional Pedagogy 9(2)/2019

expansion of the component of teaching practice; increase in the number and variability of educational routes; availability of several alternative ways of teacher training (programs ranging from university undergraduate and postgraduate programs to highly qualified pedagogical courses); updating of the content of programs for the training of foreign language teachers; diversification of forms and methods of training; internationalization of the content of professional training.

Prospects for further research include studying the experience of future foreign language teachers' training in Germany, Belgium, France and Great Britain.

\section{REFERENCES}

1. Common European Framework of Reference for Languages: Learning, Teaching, Assessment. (2001). Cambridge, MA: Cambridge University Press.

2. Jakowicka, M. (2008). Nauczyciel w ksztal ceniu I doskonaleniu w kontekscie reformy edukacji. Warszawa: Eurydice.

3. Kelly, M., Grenfell, M., Gallagher-Brett, A., Jones, D., Richard, L., \& HilmarssonDunn, A. (2002). The training of teachers of a foreign language: developments in Europe. A Report to the European Commission Directorate General for Education and Culture. Retrieved from http://ec.europa.eu/education/languages/pdf/doc493 en.pdf.

4. Kwiatkowska-Kowal, B. (2015). Kanon treści pedagogicznej edukacji akademickiej nauczycieli. Studia Pedagogiczne, LXI, 159-189.

5. Mielnik, S. (2018). Szumilas o standardach w kształceniu nauczycieli. Retrieved from http://www.rp.pl/artykul/15,925492-Szumilas--bardziej-praktyczne-ksztalcenienauczycieli.html.

6. Newby, D., Allan, R., Fenner, A., Jones, B., Komorowska, H., \& Soghikyan, K. (Eds.). (2007). European Portfolio for Student Teachers of Languages. A reflection tool for language teacher education. Strasbourg/Graz: Council of Europe/European Center for Modern Languages, $89 \mathrm{p}$.

7. Reporting stanie edukacji. (2015). Retrieved from http://eduentuzjasci.pl/p1/ component/content/article/126-informacje/artykul/233-raport-o-stanie-edukacji-2015.html.

8. Rozporzadzenie ministra edukacji narodowej z dnia 18 lipca 2006 r., No. 128, poz. 897. (2006). Retrieved from http://www.infor.pl/dziennikustaw,rok, 2006, $\mathrm{nr} 128 / \mathrm{poz}$, 897, spis, rozporzadzenie-ministraedukacji-narodowej-w-sprawie-standardow-ksztalcenia.html.

9. Regulamin organizacji i realizacji praktyk pedagogicznych realizowanych $w$ ramach projektu "Nowa jakość praktyk pedagogicznych". (2016). Retrieved from http://www.praktyki.awf.wroc.pl/Stronka/REGULAMIN.

10. Williams, G. (2012). Globalization, modernity and language: New perspectives on language in education. Retrieved from http://eunom.uoc.edu. 